\title{
Pengembangan Alat Peraga Papan Positif Negatif Berbasis Metode Montessori pada Siswa dengan ADHD
}

\author{
Utin Desy Susiaty ${ }^{*}$, Muhamad Firdaus ${ }^{2}$, Novi Andriati ${ }^{3}$ \\ 1*2,3Fakultas Pendidikan MIPA dan Teknologi, IKIP PGRI Pontianak. \\ Jalan Ampera No. 88, Pontianak, Kalimantan Barat, Indonesia \\ 1*d3or4f4ty4@gmail.com; 2kiranafirdiani@gmail.com; 3 novieandriaty@yahoo.co.id
}

Artikel diterima: 02-10-2020, direvisi: 29-01-2021, diterbitkan: 31-01-2021

\begin{abstract}
Abstrak
Hambatan guru dalam menyampaikan materi adalah kurangnya penggunaan benda-benda konkrit dalam setiap pembelajaran. Penelitian bertujuan untuk mengetahui: (1) rancangan dan implementasi alat peraga papan positif negatif berbasis metode montessori pada siswa dengan ADHD (Attention Deficit Hyperactivity Disorder); dan (2) sejauh mana kelayakan alat peraga papan positif negatif berbasis metode montessori ini dalam membantu siswa dengan ADHD. Penelitian ini merupakan penelitian pengembangan menurut Borg \& Gall. Subjek dalam penelitian dan pengembangan alat peraga ini adalah siswa-siswi pada salah satu SLB yang terdapat di Kota Pontianak tahun ajaran 2020-2021 dan guru mata pelajaran matematika. Data penelitian diperoleh berdasarkan penilaian oleh pakar/ahli terhadap alat peraga. Hasil penelitian adalah: (1) rancangan dan implementasi alat peraga papan positif negatif berbasis metode montessori pada siswa dengan ADHD memenuhi kriteria valid sebagai media pembelajaran berupa alat peraga dengan kategori sangat valid; (2) alat peraga papan positif negatif berbasis metode montessori layak sebagai media pembelajaran dalam membantu siswa dengan ADHD. Hasil penelitian digunakan sebagai sumbangan pemikiran bagi guru maupun calon guru pendidikan matematika untuk selalu melakukan inovasi dalam pembelajaran matematika demi tercapainya tujuan pembelajaran siswa sekolah umum maupun SLB.

Kata Kunci: ADHD, alat peraga, metode Montessori, papan positif negatif.
\end{abstract}

\section{Development of Montessori Method-Based Positive Negative Board Props for Students with ADHD}

\begin{abstract}
The teacher's obstacle in delivering the material is the lack of using concrete objects in every lesson. The research aims to look at: (1) the design and implementation of positive-negative board props based on the Montessori method in students with ADHD (Attention Deficit Hyperactivity Disorder); and (2) the appropriateness of this Montessori method based positive board props in helping students with ADHD. This research is development research according to Borg \& Gall. The subjects in the research and development of this teaching aid are students at one of the special schools in Pontianak City for the 2020-2021 academic year and teachers of mathematics. Research data based on the results by experts/experts on teaching aids. The results of the study were: (1) The design and implementation of positive board props based on the Montessori method for students with ADHD met the valid criteria as learning media in the form of teaching aids with very valid categories; (2) the positive board props based on the negative Montessori method are feasible as a learning medium in helping students with ADHD. The results of the research are used as a contribution of thought for teachers or prospective mathematics education teachers to always innovate in mathematics learning to achieve the learning objectives of students in public schools and special schools.

Keyword: ADHD, Montessori method, props, positive negative board.
\end{abstract}




\section{Pendahuluan}

Matematika merupakan mata pelajaran wajib pada usia sekolah (Sumartini, dkk., 2020; Siregar \& Sari, 2020). Pemahaman materi pada pembelajaran matematika yang abstrak pada anak memerlukan suatu alat bantu (Afriansyah, 2015; Robiana \& Handoko, 2020). Alat bantu yang dimaksud adalah alat peraga. Penyampaian materi oleh guru dapat dibantu dengan menggunakan alat peraga terhadap anak berkebutuhan khusus (Mariyah dkk., 2017).

Anak yang berbeda dengan anak-anak pada umumnya dan seusianya adalah anak berkebutuhan khusus. Anak dengan penanganan khusus berkaitan gangguan perkembangan dan kelainan yang dialaminya adalah anak berkebutuhan khusus (Amalia, 2018). Anak ADHD merupakan salah satu dari anak yang berkebutuhan khusus. Gangguan kesehatan emosional/perilaku yang didiagnosis pada anak adalah ADHD (Jenifer \& Dkk, 2014). Attention Deficit and Hyperactivity Disorder (ADHD) atau dikenal dengan Gangguan Pemusatan Perhatian dan Hiperaktivitas (GPPH). Suatu kondisi medis disfungsi otak yang terjadi pada seseorang dengan kesulitan mengendalikan impuls, menghambat perilaku, dan tidak mendukung rentang perhatian atau rentang perhatian mudah teralihkan disebut ADHD (Chrisna, 2014).

Gejala gangguan fungsi perkembangan saraf berupa ketidakmampuan dalam memusatkan perhatian, hiperaktivitas dan impulsivitas diluar usia perkembangan didefinisikan sebagai ADHD dalam Diagnostic and Statistical Manual of Mental Disorder edisi ke-5 (DSM-5) (American Psychiatric Association, 2013). ADHD atau Gangguan Pemusatan Perhatian dan Hiperaktivitas (GPPH) adalah salah satu masalah psikiatri utama yang sering ditemukan pada anak (Eapen dkk., 2009). Salah satu gangguan kejiwaan yang paling sering didiagnosiskan oleh psikiater pada anak-anak disebut ADHD (Karunia \& Cahyanti, 2016).

Menurut Wakhaj \& Rofiah (2018) anak dengan gangguan ADHD di dalam kelas berperilaku sering berteriak, berjalan atau berlari dan mengganggu teman lainnya sehingga akan mengganggu proses belajar mengajar dan memberikan pengaruh negatif terhadap peserta didik lainnya serta keoptimalan kegiatan belajar mengajar tidak tercapai. Hal ini sejalan dengan pendapat yang dikemukakan oleh Widodo dkk. (2020) bahwa siswa yang mengalami gangguan ADHD pada umumnya memiliki masalah dengan perilaku sosial maupun dalam bidang akademik. Berdasarkan paparan tersebut dalam proses pembelajaran di kelas siswa dengan ADHD memerlukan suatu inovasi pembelajaran yang dapat membantu mereka untuk mencapai tujuan dari pembelajaran itu sendiri khususnya pembelajaran matematika.

Anak merasa kurang tertarik dan mudah bosan terkadang terbentuk pada pembelajaran di kelas. Agar pembelajaran 
dapat diberikan secara optimal maka guru perlu mencari alternatif yang inovatif dan menarik (Afriansyah \& Dahlan, 2017; Junika, Izzati, \& Tambunan, 2020; Sari \& Afriansyah, 2020). Terlebih untuk anak berkebutuhan khusus dimana mereka membutuhkan pendampingan dan perlakuan khusus untuk dapat menyeimbangkan kemampuan akademiknya dengan anak yang tidak mengalami kebutuhan khusus. Bendabenda konkrit sangat diperlukan oleh anak berkebutuhan khusus dalam membantu memahami suatu materi pembelajaran. Hambatan guru dalam menyampaikan materi adalah kurangnya penggunaan benda-benda konkrit dalam setiap pembelajaran (Mariyah et al., 2017).

Untuk mengatasi masalah tersebut, diperlukan alternatif cara belajar yang dapat memotivasi hasil belajar anak berkebutuhan khusus yaitu siswa dengan ADHD. Salah satu alternatif tersebut adalah menerapkan pembelajaran dengan menggunakan alat peraga (Nugraha \& Sundayana, 2014; Suwarsih. 2018; Listiani, 2020). Menurut Elly (2010) media pengajaran yang mengandung atau membawakan ciri-ciri dari konsep yang dipelajari merupakan alat peraga. Selanjutnya, segala sesuatu yang dapat digunakan untuk menyatakan pesan merangsang pikiran, perasaan dan perhatian dan kemauan siswa sehingga dapat mendorong proses belajar adalah alat peraga (Sundayana, 2013; Tarusu, 2018). Benda konkrit diperlukan dalam mempelajari materi penjumlahan dan pengurangan bilangan bulat agar memudahkan siswa untuk memahami materi tersebut. Dalam penelitian ini yang digunakan adalah benda konkrit berupa alat peraga papan positif negative berbasis metode montessori. Alat peraga papan positif negatif adalah alat peraga yang menggunakan papan tulis magnetik dan menggunakan alat bantu berupa magnet bulat seperti lingkaran dan berwarna (Ratnasari dkk., 2019).

Selanjutnya Mariyah et al (2017) mengemukakan bahwa alat peraga montessori adalah jenis alat peraga yang sudah digunakan di berbagai negara di dunia. Maria Montesori adalah penddidik pendidik asal Italia yang mengenalkan alat peraga montessori. Konsep dasar tentang ilmu pengetahuan, pengamatan terhadap anak-anak, dan pedagogi merupakan metode pendidikan Montessori. Ciri-ciri yang sudah disesuaikan dengan tingkat perkembangan anak merupakan alat peraga yang dikembangkan dalam Montessori. Ciri-ciri yang dimaksud yaitu sebagai berikut (Montessori, 2002): (1) menarik artinya adalah pembelajaran yang diarahkan bagi pengembangan panca indra anak. Agar anak tertarik untuk menyentuh, meraba, dan memegangnya, maka alat peraga dibuat dengan memperhatikan warna, kontur permukaan yang lembut, dan beratnya; (2) bergradasi mengandung arti bahwa alat peraga disesuaikan dengan warna, bentuk, dan usia anak. Pembentukan konsep belajar 
anak mulai dari melibatkan panca indra anak dan bisa digunakan untuk anak-anak dari beragam usia dimungkinkan dengan penggunaan alat peraga bergradasi; (3) auto-correction artinya anak akan mengetahui jika mereka melakukan kesalahan saat menggunakan alat peraga tersebut dengan pengendali kesalahan yang terdapat pada alat peraga itu sendiri; (4) auto-education artinya pengembangan kemampuan anak untuk belajar secara mandiri terdapat pada alat peraga; (5) kontekstual memiliki arti bahwa lingkungan yang ada di sekitar anak memiliki kesesuaian dengan alat peraga. Selain itu, material yang ada di alam sekitar sebagai bahan dalam pembuatan alat peraga.

Berdasarkan paparan tersebut, peneliti melakukan penelitian pengembangan yang berjudul Pengembangan Alat Peraga Papan Positif Negatif Berbasis Metode Montessori pada Siswa dengan ADHD bertujuan untuk mengetahui rancangan dan implementasi alat peraga papan positif negatif berbasis metode montessori pada siswa dengan ADHD serta sejauh mana kelayakan alat peraga papan positif negatif berbasis metode montessori ini dalam membantu siswa dengan ADHD. Penelitian ini dilatarbelakangi juga oleh penelitian terdahulu yaitu antara lain penelitian yang dilakukan oleh Mariyah dkk. (2017) yang memaparkan bahwa alat peraga papan penjumlahan dan pengurangan dengan kualitas yang sangat baik serta dilengkapi dengan album berupa petunjuk cara penggunaan dapat meningkatkan kemampuan belajar matematika pada anak dengan ADHD. Selanjutnya, penelitian yang dilakukan oleh Ratnasari dkk. (2019) mengemukakan bahwa alat peraga papan positif negatif dengan tingkat kriteria kevalidan sangat valid dihasilkan dari penelitian pengembangan alat peraga papan positif negatif berbasis masalah terhadap kemampuan koneksi matematis pada siswa SMP.

\section{Metode}

Metode penelitian dan pengembangan atau Research and Development (R\&D) adalah metode penelitian yang digunakan dalam penelitian ini. Diagram model prosedural pengembangan media menurut Borg \& Gall (1983) adalah model prosedural atau langkah-langkah umum yang digunakan. Langkah-langkah model prosedural yang digunakan oleh peneliti memiliki perbedaan yang di lakukan oleh Borg \& Gall (1983) yaitu peneliti dalam memvalidasi alat peraga hanya melakukan sekali putaran dikarenakan tidak melakukan produksi massal terhadap alat peraga yang telah dikembangkan. Berikut langkah prosedural yang dilakukan oleh peneliti: (1) analisis kebutuhan dilakukan dengan cara mewawancarai guru dan untuk mengetahui seberapa jauh pengetahuan konsep operasi bilangan bulat diberikan pre-test kepada siswa; (2) penyusunan alat peraga untuk perencanaan awal melalui proses validasi 
oleh pakar media; (3) uji coba kepada guru dilakukan dengan tujuan untuk mengetahui apakah alat peraga yang dikembangkan sudah sesuai dengan tujuan khusus dan mengumpulkan informasi yang dapat dipakai untuk meningkatkan alat peraga sebagai keperluan perbaikan; (4) penyusunan alat peraga untuk revisi alat peraga dikerjakan berdasarkan hasil validitas oleh para ahli dan uji coba kepada guru; (5) uji coba kepada siswa dilakukan setelah proses revisi alat peraga dan dirasa alat peraga yang dibuat sudah sesuai dengan tujuan khusus; (6) evaluasi produk dilakukan berdasarkan data yang diperoleh dari hasil post-test dan penyebaran angket untuk siswa mengenai kelayakan alat peraga yang dibuat. Setelah data diperoleh kemudian data dianalisis sebagai evaluasi alat peraga. Penelitian ini digunakan untuk mengembangkan alat peraga papan positif negatif berbasis metode montessori pada siswa dengan ADHD. Siswa-siswi dengan ADHD dan guru matematika yang mengajar pada salah satu SLB yang terdapat di Kota Pontianak merupakan subjek utama dalam penelitian ini. Objek dari penelitian ini adalah pengembangan alat peraga papan positif negatif berbasis metode montessori pada siswa dengan ADHD dalam membantu siswa memahami konsep matematika khususnya materi operasi bilangan bulat. Lembar validasi ahli media dan materi digunakan sebagai teknik pengambilan data.

\section{Hasil dan Pembahasan}

\section{A. Hasil Penelitian}

Penelitian ini dilakukan dengan model pengembangan Borg \& Gall (1983) yang memiliki 10 langkah yang sudah dimodifikasi hanya sampai pada langkah ketujuh yaitu revisi desain. Penelitian ini mengembangkan suatu alat peraga yaitu pengembangan alat peraga papan positif negatif berbasis metode montessori pada siswa dengan ADHD. Adapun proses yang telah dilakukan dalam penelitian ini adalah sebagai berikut. Dalam penelitian ini langkah awal yang dilakukan dalam proses penelitian untuk mengembangkan adalah dengan mengidentifikasi kebutuhan siswa. Ditinjau dari siswa berkebutuhan khusus ADHD yang membutuhkan model pembelajaran yang tepat dan alat peraga yang efektif serta menarik untuk memudahkan siswa memahami materi pembelajaran. Berdasarkan potensi dan masalah tersebut, penelitian ini dilakukan untuk mengembangkan alat peraga papan positif negatif berbasis metode montessori pada siswa dengan ADHD yang disesuikan dengan kurikulum 2013 serta materi operasi penjumlahan dan pengurangan pada siswa berkebutuhan khusus pada salah satu SLB yang terdapat di Kota Pontianak dengan harapan memudahkan siswa untuk memahami materi serta mengembangkan kemampuan matematisnya. Setelah mengetahui potensi dan masalah pada penelitian ini, selanjutnya mencari informasi terkait dengan produk yang dikembangkan secara 
relevan terhadap potensi dan masalah yang ditemukan. Dalam pengumpulan data atau informasi dilakukan melalui wawancara tenaga pendidik terkait untuk mencari kebutuhan siswa berkebutuhan khusus yaitu ADHD dalam mempelajari matematika. Kemudian informasi serupa juga ditemukan melalui penelitian terdahulu sebagai tambahan dalam pengumpulan data. Pengumpulan data tidak hanya memprioritaskan suatu produk yang hanya bisa digunakan saja, tetapi kegunaan dan peruntukkannya terhadap siswa.

Desain produk diawali dengan mendesain alat peraga papan positif negatif serta desain buku panduan penggunaan alat peraga papan positif negatif. Desain buku panduan penggunaan alat peraga papan positif negatif dibuat dengan menggunakan Microsoft Word. Buku panduan berisi langkah-langkah penggunaan alat peraga papan positif negatif. Setelah desain produk awal diselesaikan, kemudian diserahkan kepada validator untuk divalidasi dan dinilai kelayakannya. Selain itu untuk mengantisipasi kesalahan-kesalahan saat uji coba lapangan digunakanlah validasi ahli. Dalam penelitian ini, untuk mendapatkan masukan atau saran dalam menyempurnakan alat peraga serta buku panduan tersebut, maka dilakukan proses rangkaian validasi oleh tiga orang validator. Bahan untuk merevisi alat peraga dan buku panduan penggunaan alat peraga diperoleh dari saran-saran validator. Validator memberikan penilaian berdasarkan dengan lembar penilaian yang telah disusun. Terkait dengan validasi media, terdapat lima indikator yang dinilai, diantaranya auto education (mandiri), auto correction, menarik, bergradasi, dan kontekstual. Sedangkan untuk validasi materi terdapat tiga aspek penilaian yaitu keterkaitan dengan bahan ajar, keterkaitan dengan materi, dan keakuratan alat peraga.

Hasil penilaian oleh ahli media ditunjukkan pada tabel 1.

Tabel 1.

Hasil Validasi Media oleh Validator

\begin{tabular}{|llcl|}
\hline No & Validator & Persentase & Keterangan \\
\hline 1 & Validator I & $92 \%$ & Sangat Valid \\
\hline 2 & Validator II & $96 \%$ & Sangat Valid \\
\hline 3 & Validator III & $96 \%$ & Sangat Valid \\
\hline & Rata-rata & $94,67 \%$ & Sangat Valid \\
\hline
\end{tabular}

Hasil Validasi Media oleh Validator

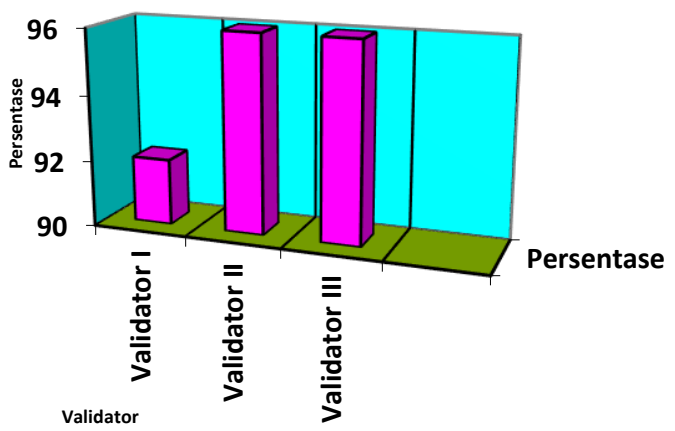

Gambar 1. Hasil Validasi Media oleh Validator

Berdasarkan hasil dari tabel dan gambar 1 diperoleh nilai rata-rata dari hasil penilaian oleh ahli media sebesar $94,67 \%$ dengan katagori sangat valid, sehingga alat peraga layak digunakan 
untuk uji coba. Hasil penilaian oleh ahli materi ditunjukkan pada tabel 2 .

Tabel 2.

Hasil Validasi Materi oleh Validator

\begin{tabular}{|llcl|}
\hline No & Validator & Persentase & Keterangan \\
\hline 1 & Validator I & $93,33 \%$ & Sangat Valid \\
\hline 2 & $\begin{array}{l}\text { Validator } \\
\text { II }\end{array}$ & $96,19 \%$ & Sangat Valid \\
\hline 3 & $\begin{array}{l}\text { Validator } \\
\text { III }\end{array}$ & $96,24 \%$ & Sangat Valid \\
\hline & Rata-rata & $94,91 \%$ & Sangat Valid \\
\hline
\end{tabular}

Hasil Validasi Media oleh Validator

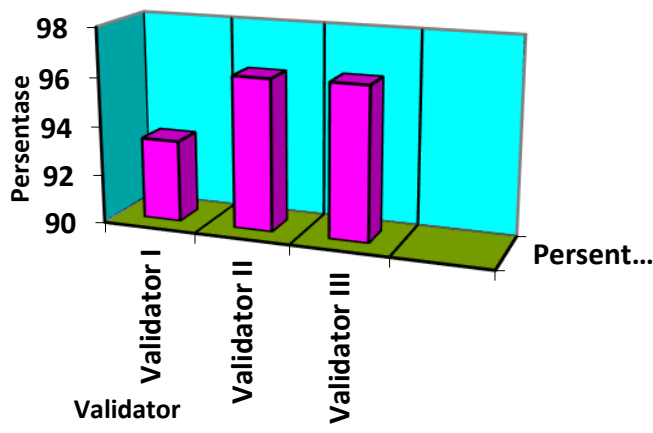

Gambar 2. Hasil Validasi Materi oleh Validator

Berdasarkan hasil dari tabel dan gambar 2 diperoleh nilai rata-rata dari hasil penilaian oleh ahli materi sebesar 94,91\% dengan kategori sangat valid, sehingga layak digunakan untuk uji coba. Tabel 1 dan 2 menggunakan kriteria tingkat kevalidan yang diukur dengan perhitungan skala likert ditunjukkan pada tabel 3.

Tabel 3.

Tingkat Kevalidan Produk

\begin{tabular}{lccl|}
\hline \multicolumn{1}{c}{ Penilaian } & $\begin{array}{c}\text { Skala } \\
\text { Nilai }\end{array}$ & $\begin{array}{c}\text { Hasil Rating } \\
\text { Presentase }\end{array}$ & Keterangan \\
\hline Sangat Valid & 5 & $86 \%-100 \%$ & Tidak Revisi \\
\hline Valid & 4 & $66 \%-85 \%$ & Tidak Revisi \\
\hline Cukup Valid & 3 & $51 \%-65 \%$ & Sedikit Revisi \\
\hline Tidak Valid & 2 & $36 \%-50 \%$ & Revisi \\
\hline
\end{tabular}

Sangat Tidak $1 \quad 20 \%-35 \% \quad$ Revisi

Valid

Sumber: Riduwan (Yudhaskara, 2016)

Berdasarkan perhitungan dari ahli media dan materi, maka didapat tingkat kevalidan alat peraga papan positif negatif untuk menjawab sub masalah 1. Hasil perhitungan validasi media dan materi ditunjukkan pada tabel 4.

Tabel 4.

Rata-Rata Hasil Validasi

\begin{tabular}{llcc}
\hline No & Validator & Persentase & Keterangan \\
\hline 1 & $\begin{array}{l}\text { Ahli } \\
\text { Media }\end{array}$ & $94,67 \%$ & Sangat Valid \\
\hline 2 & $\begin{array}{l}\text { Ahli } \\
\text { Materi }\end{array}$ & $94,91 \%$ & Sangat Valid \\
\hline & Rata-rata & $94,79 \%$ & Sangat Valid
\end{tabular}

Dengan demikian dapat disimpulkan bahwa tingkat kevalidan alat peraga papan positif negatif berbasis metode montessori pada siswa dengan ADHD sebesar 94,79\% dengan kategori sangat valid. Setelah desain produk awal divalidasi oleh para ahli, maka dapat diketahui kekurangannya. Kekurangan tersebut selanjutnya akan dilakukan revisi desain. Saran-saran yang diberikan oleh para ahli pada saat validasi revisi desain ini sebagai landasan untuk menghasilkan alat peraga papan positif negative yang layak digunakan dalam proses pembelajaran. Bagian-bagian yang diperbaiki adalah sebagai berikut. 


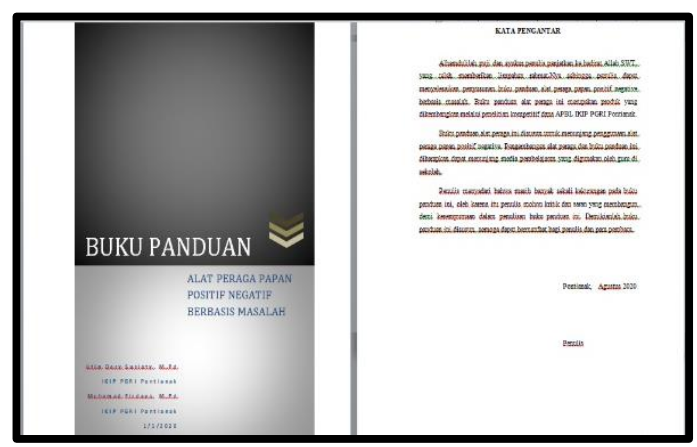

Gambar 3. Bagian Cover dan Daftar Isi

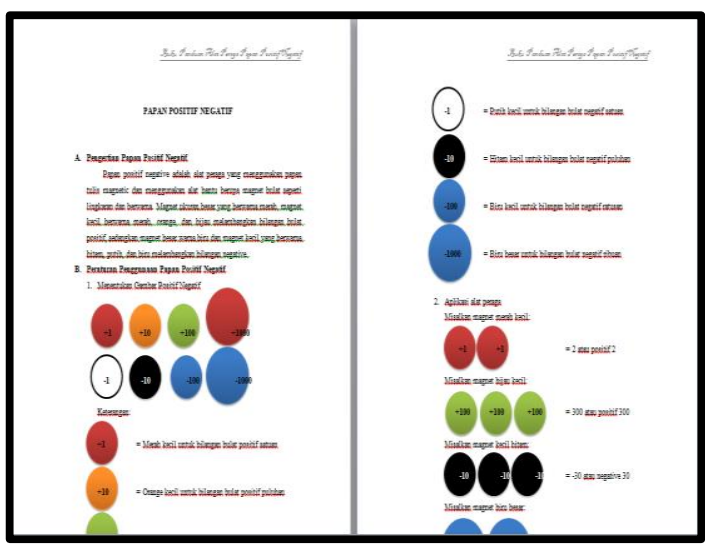

Gambar 4. Bagian Isi Buku Panduan

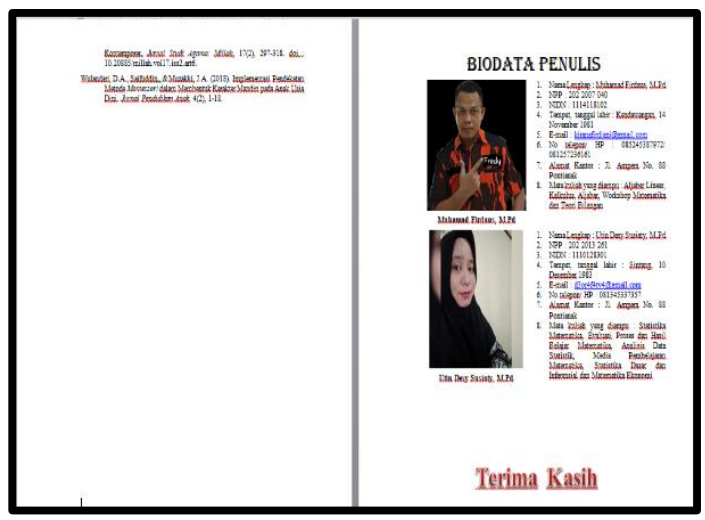

Gambar 5. Bagian Biodata Penulis

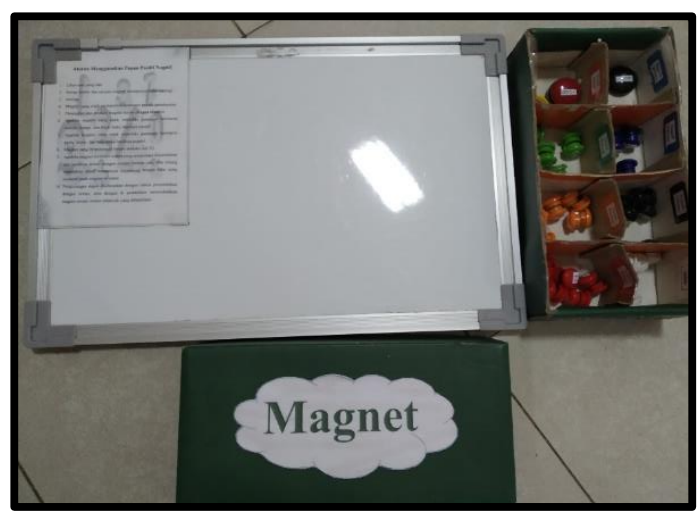

Gambar 6. Alat Peraga Papan Positif Negatif Berbasis Metode Montessori

\section{B. Pembahasan}

Proses pengembangan alat peraga papan positif negatif berbasis metode montessori pada siswa dengan ADHD menggunakan model pengembangan menurut Borg \& Gall (1983). Pada model ini terdapat 10 langkah yang dilaksanakan diantaranya (1) potensi dan masalah (2) pengumpulan data (3) desain produk (4) validasi desain (5) revisi desain (6) uji coba produk (7) revisi produk (8) uji coba pemakaian (9) revisi produk dan (10) produksi masal. Namun pada penelitian dan pengembangan ini penulis tidak menggunakan langkah 8, 9 dan 10, karena keterbatasan waktu, tenaga, dan biaya. Rancangan Borg \& Gall (1983) yang dilakukan bertujuan untuk melihat kevalidan, kepraktisan dan keefektifan alat peraga papan positif negatif. Kevalidan alat peraga papan positif negatif diketahui melalui tahap validasi oleh ahli media dan materi yang menggunakan pengukuran "skala likert". Alat peraga dalam aspek validasi media dinyatakan sangat valid dengan hasil rating 94,67\%, sedangankan 
aspek validasi materi dinyatakan sangat valid dengan hasil rating sebesar 93,33\%, sehingga memperoleh rata-rata persentase kevalidan sebesar 94\% dengan kriteria sangat valid. Setelah selesai melakukan validasi, maka tahap selanjutnya yaitu melakukan uji coba produk. Tahap uji coba ini akan dilakukan pada salah satu SLB yang terdapat di Kota Pontianak. Uji coba produk dilakukan untuk melihat kepraktisan dan keefektifan dari alat peraga papan positif negatif. Kepraktisan dalam uji coba produk dilihat dari hasil angket respon guru dan hasil angket respon siswa, sedangkan keefektifan alat peraga papan positif negatif dilihat dari hasil posttest. Uji coba produk diawali dengan mengajukan surat permohonan izin penelitian ke salah satu SLB yang terdapat di Kota Pontianak.

Setelah berkonsultasi dengan guru yang mengajar dikelas tersebut beserta Kepala Sekolah, peneliti menyelesaikan siklus penelitian pengembangan hanya sampai pada revisi desain produk berdasarkan hasil validasi. Hal ini terjadi dikarenakan dunia sedang mengalami wabah Covid-19 atau yang dikenal dengan Corona. Begitu pula halnya yang terjadi di Indonesia khususnya Pontianak Kalimantan Barat. Sebagai kebijakan pemerintah dalam mencegah penyebaran virus Covid-19 ini (Afriansyah, dkk., 2020), semua lingkungan pendidikan dilaksanakan secara daring (online). Begitu juga demikian halnya pada salah satu SLB yang terdapat di Kota Pontianak. Siswa dan siswi di SLB tersebut juga melaksanakan pembelajaran daring (online).

Peneliti sudah memikirkan berbagai solusi untuk melakukan uji coba produk peneliti. Jika produk ini disampaikan secara online, maka tidak akan bisa mengukur sampai sejauh mana produk alat peraga papan positif negatif berbasis metode montessori ini akan berdampak pada siswa dengan ADHD. Karena untuk memaksimalkan hasil penelitian ini, peneliti harus bertatap muka langsung dengan siswa dan siswa menggunakan secara langsung alat peraga tersebut. Dan hal tersebut tidak memungkinkan untuk dilakukan pada saat pandemi Covid-19 ini. $\mathrm{Hal}$ tersebutlah yang menjadi pertimbangan bagi peneliti untuk memangkas siklus penelitian pengembangan hanya sampai pada tahap revisi desain berdasarkan hasil validasi desain produk. Harapan peneliti alat peraga papan positif negatif yang dikembangkan dalam penelitian ini dapat dilanjutkan lagi oleh peneliti lain dengan skala yang lebih luas agar kualitas alat peraga benar-benar teruji dalam hal pemanfaatannya.

\section{Penutup}

Berdasarkan hasil pengembangan, penelitian, dan pembahasan terhadap alat peraga papan positif negatif berbasis metode montessori pada siswa dengan ADHD dapat simpulkan bahwa: (1) rancangan dan implementasi alat peraga papan positif negatif berbasis metode 
montessori pada siswa dengan ADHD memenuhi kriteria valid sebagai media pembelajaran berupa alat peraga dengan kategori sangat valid; (2) alat peraga papan positif negatif berbasis metode montessori layak sebagai media pembelajaran dalam membantu siswa dengan ADHD. Adapun saran dari penelitian ini agar dapat menjadi pandangan bagi pembaca dan peneliti selanjutnya antara lain: (1) alat peraga papan positif negatif yang dikembangkan dalam penelitian ini dapat dilanjutkan lagi oleh peneliti lain sampai langkah kesepuluh yaitu produksi massal dengan skala yang lebih luas. (2) alat peraga papan positif negatif yang dikembangkan masih perlu disempurnakan lagi dengan uji coba lapangan, agar kualitas alat peraga benarbenar teruji dalam hal pemanfaatannya.

\section{DAfTAR Pustaka}

Afriansyah, E. A. (2015). Students' Misconception in Decimal Numbers. In International Seminar on Teacher Education 1st ISTE UIN Suska Riau.

Afriansyah, E. A., \& Dahlan, J. A. (2017, May). Design Research in Fraction for Prospective Teachers. In 5th SEA-DR (South East Asia Development Research) International Conference 2017 (SEADRIC 2017) (pp. 91-97). Atlantis Press.

Afriansyah, E. A., Sofyan, D., Puspitasasri, N., Lurytawati, I. P., Sundayana, R., Maryati, I., ... \& Basuki, B. (2020). Edmodo E-learning Media Training for Learning Optimization. Jurnal Pekemas, 3(2), 33-39.
Amalia, R. (2018). Intervensi terhadap Anak Usia Dini yang Mengalami Gangguan ADHD Melalui Pendekatan Kognitif Perilaku dan Alderian Play Therapy. Jurnal Obsesi: Jurnal Pendidikan Anak Usia Dini, 2(1), 27. https://doi.org/10.31004/obsesi.v2i1. 4

American Psychiatric Association. (2013). Diagnostic and statistical manual of mental disorder (Edisi kelima). American Psychiatric Association.

Borg, W. R., \& Gall, M. D. (1983). Educational Research An introduction. Longman.

Chrisna, F. (2014). Wriring Skill for ADHD: Terapi dan Bimbingan Menulis untuk anak $A D H D$. Maxima.

Eapen, V., Mabrouk, A., Zoubeidi, T., Sabri, S., Yousef, S., Al-Ketbi, J., \& Al, E. (2009). Epidemiological study of attention deficit hyperactivity disorder among school children in the United Arab Emirates. Journal of Medical Sciences, 2(3), 119-127.

Elly, E. (2010). Metode Pengajaran Matematika di Sekolah Dasar. PPPG Jogjakarta.

Jenifer, \& Dkk. (2014). ADHD: Implications for School Counselors. Georgia School Counselors Association Journal, 21(1).

Junika, N., Izzati, N., \& Tambunan, L. R. (2020). Pengembangan Soal Statistika Model PISA untuk Melatih Kemampuan Literasi Statistika Siswa. Mosharafa: Jurnal Pendidikan Matematika, 9(3), 499-510.

Karunia, A., \& Cahyanti, I. N. (2016). Pengaruh Psikoedukasi tentang Pengetahuan ADHD terhadap Kemampuan Guru dalam Melakukan Deteksi Dini Masalah ADHD pada 
Siswa dan Keterampilan Intervensi Kelas. INSAN Jurnal Psikologi Dan Kesehatan Mental, 1(1), 1. https://doi.org/10.20473/jpkm.v1i12 016.1-11

Listiani, T. (2020). Penggunaan Model PACE dalam Pembelajaran Geometri Topik Bangun Ruang. Mosharafa: Jurnal Pendidikan Matematika, 9(3), 407-418.

Mariyah, Aprinastuti, \& Anggadewi. (2017). Pengembangan alat peraga untuk meningkatkan kemampuan belajar matematika pada anak dengan ADHD. Prosiding Temu IImiah $X$ Ikatan Psikologi Perkembangan Indonesia Dengan Tema Peran Psikologi Perkembangan Dalam Penumbuhan Humanitas Pada Era Digital, 5(2), 240-250. https://doi.org/10.15575/psy.v5i2.29 77

Montessori, M. (2002). The Montessori Method. Frederick A. Stokes Company.

Nugraha, A., \& Sundayana, R. (2014). Penggunaan Alat Peraga sebagai Upaya untuk Meningkatkan Prestasi Belajar dalam Memahami Konsep Bentuk Aljabar pada Siswa Kelas VIII di SMPN 2 Pasirwangi. Mosharafa: Jurnal Pendidikan Matematika, 3(3), 133-142.

Ratnasari, D., Firdaus, M., \& Susiaty, U. (2019). Pengembangan Alat Peraga Papan Positif Negatif Berbasis Masalah terhadap Kemampuan Koneksi Matematis pada Siswa SMP. Jurnal Prodi Pendidikan Matematika, 1(1), 45-33.

Robiana, A., \& Handoko, H. (2020). Pengaruh Penerapan Media UnoMath untuk Meningkatkan Kemampuan Komunikasi Matematis dan Kemandirian Belajar Siswa. Mosharafa: Jurnal Pendidikan Matematika, 9(3), 521-532.

Sari, H. M., \& Afriansyah, E. A. (2020). Analisis Miskonsepsi Siswa SMP pada Materi Operasi Hitung Bentuk Aljabar. Mosharafa: Jurnal Pendidikan Matematika, 9(3), 439-450.

Sumartini, T. S., Sunday, R., Madio, S. S., Afriansyah, E. A., Puspitasasri, N., Nuraeni, R., \& Lurytawati, I. P. (2020). Pedagogical Content Knowledge. Jurnal Pekemas, 3(1), 1012.

Sundayana, R. (2013). Media dan Alat Peraga dalam Pembelajaran Matematika. Alpabeta.

Suwarsih, S. (2018). Meningkatkan Hasil Belajar Siswa tentang Perkalian dan Pembagian Bilangan Cacah melalui Alat Peraga. Mosharafa: Jurnal Pendidikan Matematika, 7(3), 433444.

Tarusu, D. T. (2018). Kemampuan pedagogik matematika SD pada mahasiswa PGSD FIP UNIMA. Mosharafa: Jurnal Pendidikan Matematika,7(2), 263272.

Wakhaj, N. I. U., \& Rofiah, N. H. (2018). Perilaku Attention Deficit Hyperactivity Disorder (Adhd) Dalam Proses Pembelajaran (Studi Kasus Peserta Didik) Di Kelas Iv Sd Negeri Gejayan. Jurnal Fundadikdas (Fundamental Pendidikan Dasar), 1(1), 64. https://doi.org/10.12928/fundadikda s.v1i1.71

Widodo, A., Rahmatih, A. N., Novitasari, S., 
\& Nursaptini, N. (2020). Analisis Gaya Belajar Siswa ADHD (Attention Deficit Hyperactivity Disorder) di Madrasah Inklusi Lombok Barat. Jurnal Bidang Pendidikan Dasar, 4(2), 145-154. https://doi.org/10.21067/jbpd.v4i2.4 434

Yudhaskara, H. (2016). Pengembangan Media Pembelajaran Berbasis Flash Pada Standar Kompetensi Melakukan Instalasi Software Di Smk Gama Kedungadem Bojonegoro. Jurnal Pendidikan Teknik Elektro, 5(3).

\section{Riwayat Hidup PENULIS}

\section{Utin Desy Susiaty, M.Pd.}

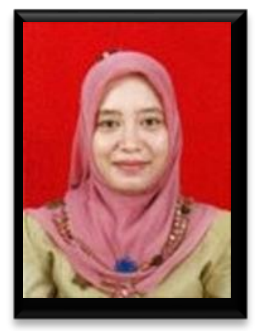

\begin{abstract}
Lahir di Sintang, 10 Desember 1983, Tenaga Pengajar di IKIP PGRI Pontianak, Studi S1 Pendidikan Matematika di STKIP PGRI Pontianak, lulus tahun 2008, dan Studi S2 Pendidikan Matematika
\end{abstract} Universitas Sebelas Maret Surakarta, lulus tahun 2015. Publikasi yang pernah dilakukan salah satunya dengan judul Developing Refutation Text to Resolve Students Misconception in Addition and Subtraction in Integers.

\section{Muhamad Firdaus, M.Pd}

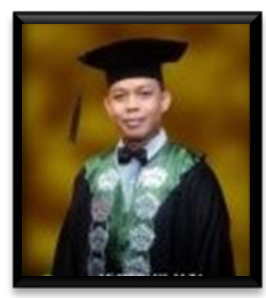

Lahir di Kendawangan, 14 November 1981, Tenaga Pengajar di IKIP PGRI Pontianak, Studi S1 Pendidikan Matematika di STKIP PGRI Pontianak, lulus tahun 2006, dan Studi S2 Pendidikan Matematika Universitas Sebelas Maret Surakarta, Iulus tahun 2012. Publikasi yang pernah dilakukan salah satunya dengan judul Kemampuan Penalaran Matematis dan Motivasi Mahasiswa Calon Guru Melalui Model Reciprocal Teaching.

\section{Novi Andriati, M.Pd.}

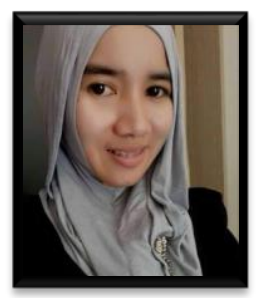

Lahir di Pontianak, 25 November 1984, Tenaga Pengajar di IKIP PGRI Pontianak, Studi S1 Bimbingan Konseling FKIP Universitas Tanjung Pura Pontianak, lulus tahun 2010, dan Studi S2 Bimbingan

Konseling Universitas Negeri Semarang, lulus tahun 2015. Publikasi yang pernah dilakukan salah satunya dengan judul Pengembangan Model Bimbingan Klasikal Dengan Teknik Role Playing Untuk Meningkatkan Kepercayaan Diri Anak TK Di Kota Pontianak. 